Volume 4 No II

ISSN 2614-2775 (Print)

Tahun 2021

ISSN 2621-8143 (Online)

\title{
THE EFFECTIVENESS OF IMPLEMENTING TEACHING MATERIALS THROUGH E-LEARNING MEDIA AND YOUTUBE TO IMPROVE THE LEARNING OF PHYSICAL EDUCATION SPORT AND HEALTH
}

\author{
Isatul Hasanah ${ }^{1}$, Adi Wijayanto ${ }^{2}$ \\ IAIN Tulungagung ${ }^{1,2}$ \\ isatulhasanah@gmail.com ${ }^{1}$, adiwijayanto@iain-tulungagung.ac.id ${ }^{2}$
}

\begin{abstract}
Abstrack
The development of science and technology in this globalization era has had a big impact on whole fields, especially in education. The study aims to learn the effectiveness of teaching materials through e-learning media and youtube to improve the results of study sports and health. This research is a quantitative. The sample was 65 students of elementary students. The data analysis used by researchers is the percentage statistical formula. The finding of this research is that the use of e-learning media with web form is more interest to the students than youtube as a medium for learning sports and health. The Percentages are obtained $77 \%$ for use e-learning media and 22\% for youtube. The use of e-learning media can also minimize the boredom experienced by students during the learning process. It can be proved that 57\% of students answering with the affirmative answer category and $40 \%$ rate by the affirmative answer category. Students are also have enthusiastic when teachers use e-learning rather than youtube media in the learning process with $66 \%$ affirmative answer and $17 \%$ agree. When the learning is done at home, the students freely use social media. The use of social media cannot be controlled whether in positive or negative ways. Based on the these data obtained by researchers that students are using a 40\% level of social media to engage in entertainment such as gaming and $41 \%$ to learn physical education materials related to sports and health. Therefore, the use of elearning media is effective in improving students' learning.
\end{abstract}

Keyword: Effectiveness, Teaching Material, E-learning Media and Youtube, Physical Education Sport and Health

Accepted: 9th of July 2021

Correspondence author: Isatul Hasanah, IAIN Tulungagung, Indonesia. E-Mail: isatulhasanah@gmail.com

DOI http://dx.doi.org/10.31851/hon.v4i25551

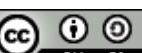

Jurnal Halaman Olahraga Nusantara licensed under a Creative Commons Attribution-ShareAlike 4.0 International License 


\section{INTRODUCTION}

The need for education has a very important role and has a very large influence. In the learning process, of course, there are educational actors, namely a teacher and students. Education aims to change the mindset and add insight, knowledge possessed by previous students (Wayang Cong Sujana, 2019). Teaching and learning process activities certainly require learning resources that can be used in the learning process to achieve the predetermined goals. One of the learning resources that can be used is teaching materials. Teaching material can facilitate the learning process when learning is taking place. Not only that, but teaching materials can encourage the learning process to be more effective, directed, and efficient.

A school is a place of organization for the community in obtaining knowledge (Andi Prastowo, 2016). However, in the current pandemic conditions, schools can only be used as a supporting factor in the learning process. Because schools cannot be used as teaching and learning activities. This has become one of the new problems, especially for teachers who play a direct role in the world of education. Teachers and educators as important elements in teaching are required to make an unprecedented massive migration from traditional face-to-face education to online education or distance education (Asri \& Lely Octaviana, 2021). The government still recommends that the process of teaching and learning activities must still be carried out even in this pandemic condition. Therefore, learning can still be carried out with the presence of utilizing technology that we can use to keep the learning going. Teachers in physical education are expected to have,broad skills and knowledge to provide a good experience for students to achieve success in educating (Arisman, 2018).

Education in the $21^{\text {st }}$ century is often referred to as the industrial generation 4.0 which is known as the century of openness and globalization (Kris Helge, 2013). This is marked by the development of information technology and 
telecommunications systems in various fields of life. Including in the field of education itself. One of the effects of technology in education is the emergence of new things that utilize the internet network in the learning process (Lies Sudibyo, 2011). So that in the implementation of learning also requires electronic services in the form of audio and video. learning Online is a process that brings together students with a teacher to have a virtual interaction by utilizing technology assistance (Pebria Dheni Purnasari, 2020). Moreover, many media can be used to support learning. Teachers can take advantage of technology-based media such as Google Classroom, Google Meet, Zoom, Youtube, E-Learning, Edmodo, $\mathrm{CBT}$, even learning online can be done with virtual messaging media, namely Whatsapp. The very varied media is certainly an option for a teacher to choose media that is liked by students and attracts students' attention. Therefore, in this era of globalization, a teacher must be able to have the desire or literacy of technology. To have an impact on the knowledge that will be obtained by students. Even everyday technology is projected to continue to grow along with the increase in the number of social media users. So it can be concluded that the use of social media not only has a negative impact but also has a positive impact.

In general, education has a very important role in developing human resources (Chenicheri Sid Nair, Arun Patil, Patricie Mertova, 2012). So that none other than the rise of technological systems can help teachers and students in obtaining information. Especially nowadays, information is very easy to get with the internet media. The Effectiveness of the learning process is largely determined by the extent of the knowledge gained by students. Therefore, the learning process is expected to give a meaningful impression to students (Clarence Mybee, 2018). So that students can improve the quality of knowledge previously possessed.

Learning can be done with the help of teaching materials. Because in the teaching materials there is a design in carrying out the learning process (Syarif Sumantri, 2017). However, in the current pandemic conditions, teaching materials 
are not used optimally. Likewise, when the learning process is carried out offline, the material in the teaching materials is not fully realized in the form of practice. Whereas physical education learning is identical to the existence of a movement. Therefore, in this learning, students need to practice directly to mix and match theory and practice. The use of technology today is very helpful for students to practice directly (Babitha Elsa Oommen, 2020). Although learning is done at home without meeting the teacher. However, students are helped by the existence of internet media that can provide examples related to the material to be studied. Judging from the facts on the ground that the use of media is ELearning and Youtube very much in demand by children. Because the media is already familiar to students. So that students are very easy to apply the media and are very suitable for use in the learning process.

Given the importance of physical education, sports, and health at the elementary school level in supporting the process of child development (Sabaruddin Yunis Bangun, 2016). Coupled with the proliferation of technological systems that can support the condition of children, so that it can be a business opportunity in optimizing the learning process. In learning physical education, sports and health are expected to be used as a vehicle for compensating children's movements. So that it can create a conducive vehicle, design, and foster children's desire for movement (Sabarudin, 2016). Therefore, the learning process of physical education and sports health should cultivated optimally in improving the quality of which is supported by the presence of a component in in it.

In harmony with one of the efforts in achieving the goals of physical education, sports and health are not only a process of developing knowledge but also generating individual potential that can improve physical, intellectual, social, and moral abilities oriented to life skills. One of the targets of physical education in sports and health is that students can improve physical fitness and basic movement skills with fine nerve-muscle coordination which will provide benefits 
for everyday life (Mark Latash., 2015). Therefore, indirectly, physical education, sports, and health become a strong foundation for children in mastering their movement skills. So that it becomes one of the foundations for children in directing under the substance.

The use of social media can be accessed via mobile phones and Indonesia is one of the countries that ranks 3rd with the largest internet users after China. This does not rule out the possibility that the Indonesian state also has a very large opportunity in improving the quality of learning. In this case, social media is one of the needs of the community. But in reality, the number of media that can be used in the learning process does not exceed media e-learning and youtube which can attract students' attention. Because the media is very easy to use in the learning process. Learning that is carried out with the system online current, really provides an insight or sharpens students' abilities (Zaheer Allam, 2020). Mobile is initially only a tool to play the game alone, but in these conditions, the mobile phone can help in maximizing the learning process.

Improving the quality of quality learning requires a long process. So that a teacher must be able to choose a media that can be used in the teaching and learning process. One of the media that can be used by teachers is mediaelearning and youtube. The media is used as a substitute for teaching materials during online learning. The use of the media is of course adapted to the needs of current students, who cannot practice directly (Urs Gttiker, 2013). Therefore, the use of media e-learning and youtube is very useful for students in following the learning process to the fullest. In media youtube addition to being easy to use can also help students understand learning material. Because the presentation is interspersed with pictures and videos that can be seen by students and can be imitated by students even though learning is done at home. But on the other hand, media is e-learning also very helpful for a teacher in delivering learning materials. The media is also very easy to use so that students do not feel confused in applying it. Because the form of e-learning is in the form of a web, so students can access it 
whenever they want and students can also view videos contained on the web. This is certainly a problem which of the two media are equally in demand by students. Therefore, researchers want to know the extent to which the effectiveness of the use of teaching materials through media e-learning and youtube in improving learning outcomes of physical education, sports, and health. When viewed from reality, the two media tend to be liked by children and can maximize the learning process online. Therefore, researchers will analyze the use of teaching materials through e-learning and Youtube media and the balance of students in using social media, especially at the elementary school level.

\section{METHOD}

This research is a descriptive study using a quantitative approach. This quantitative descriptive research is research that describes events that are happening at present. In this study, researchers analyzed and interpreted the existence of these events. The purpose of using this type of research is to find out an overview of the effectiveness of using teaching materials through media e-learning and youtube during the pandemi covid-19 in improving physical education learning outcomes Sports and health. The population of this study was all students at MI Bustanul Ulum Noterejo Gondang Tulungagung consisting of grades 1-6 totaling 479 students. The sample taken is the 5 th-grade students totaling 65 students. The sampling technique in this research is using purposive sampling with the aim that the sample used can meet the requirements under the research that the researcher is doing. In the data collection technique, the researcher used an instrument in the form of a questionnaire containing the types of closed and open questions that were distributed using a google form. The questionnaire was used by researchers to obtain the effectiveness of using media e-learning and youtube. The assessment used by the researcher on the questionnaire instrument uses a Likert scale based on values 1 to 5. The data analysis used by the researcher uses the percentage statistical formula. 
The details of the overall population and the scoring criteria for the analysis of the questionnaire data are presented in Tables 1 and 2 below.

Table 1. Details of the Overall Population

\begin{tabular}{cccc}
\hline \multirow{2}{*}{ Class } & \multicolumn{2}{c}{ Gender } & \multirow{2}{*}{ Total } \\
\cline { 2 - 3 } & Male & Female \\
\hline 1 & 37 & 44 & 81 \\
2 & 54 & 45 & 99 \\
3 & 40 & 48 & 88 \\
4 & 33 & 41 & 74 \\
5 & 28 & 37 & 65 \\
6 & 34 & 38 & 72 \\
\hline
\end{tabular}

Table 2. Criteria Data Analysis Questionnaire Scoring

\begin{tabular}{ccccc}
\hline \multicolumn{2}{c}{ Score } & \multicolumn{2}{c}{ Qualification } & \multirow{2}{*}{ Follow-up } \\
\cline { 1 - 4 } Criteria & Presentage & Appropriate & Effective & \\
\hline 5 & $81 \%-100 \%$ & Very Appropriate & $\begin{array}{c}\text { Very } \\
\text { Effective }\end{array}$ & \\
& & & Implementation \\
4 & $61 \%-80 \%$ & Appropriate & Effective & Implementation \\
3 & $41 \%-60 \%$ & Sufficiently & Sufficiently & Need to \\
& & Appropriate & Effective & Revision \\
2 & $21 \%-40 \%$ & Not Appropriate & Not Effective & Revision \\
1 & $0 \%-20 \%$ & Very Not & Very & Revision \\
& & Appropriate & Ineffective & \\
\hline
\end{tabular}

\section{RESULTS AND DISCUSSION}

Learning activities carried out online, it is possible for students not to gain broad knowledge. Instead, students can mix and match the material that has been given by the teacher with the material found by themselves (Andi Prastowo, 2016). In this case, the effectiveness of learning needs to be considered, especially for teachers. Because this is one of the success rates of students in gaining knowledge. 
In this era of globalization, technology is very useful for students and the wider community. Technology can be utilized in all aspects to achieve maximum goals.

Especially in the field of education today, the use of technology has a very great impact on the learning process online (Wahyuningtyas \& Sulasmono, 2020). This research was conducted at the elementary school level with a sample of 65 students consisting of $55 \%$ female and $45 \%$ male. All respondents came from district Tulungagung. The graph can be seen in the image below.

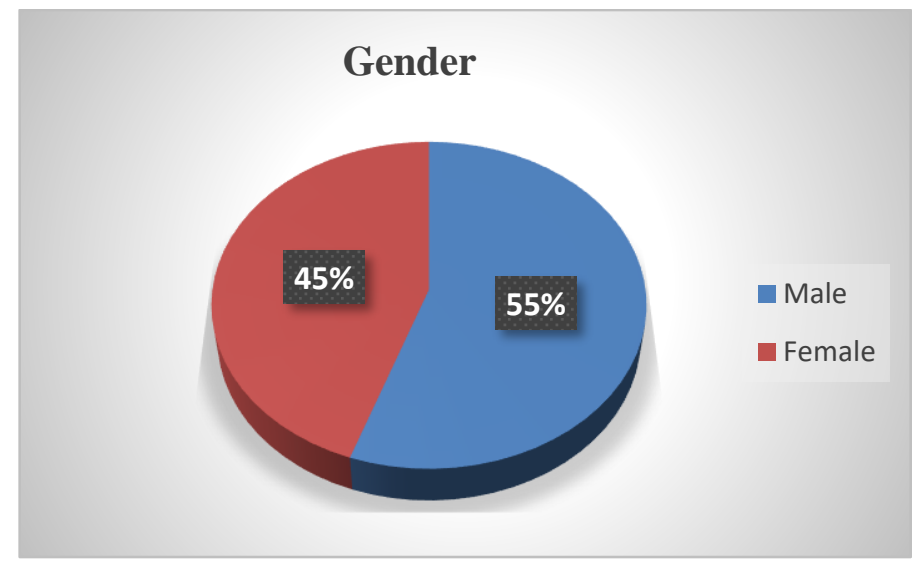

Figure 1. Gender

The development of technology and information greatly affects various fields of life, one of which is the field of education. Therefore, educational institutions must be able to anticipate continuous development and seek a program that is under the needs of students (Silahuddin, 2015). Based on the analysis of the data used by researchers through the instrument of inquiry found that the presence of the effectiveness of the use of teaching materials through the medium of elearning more desirable than the media youtube. Because media is e-learning very easy to access and does not drain data, it is more practical and does not consume memory. The presentation of this media $e$-learning is also very complete starting from the content of the material, assessments, and assignments that will be given by the teacher. So that teachers are more likely to use e-media 
learning than youtube. Students can also access at will and teachers can also monitor the assignments that have been given to students. On the other hand, this media e-learning also contains teaching materials that link youtube. So that students can learn the material to the fullest. Especially in the subjects of physical education, sports, and health, the use of e-learning is very helpful for students in completing tasks given by teachers online. So that students not only know what elearning is, but students can also add insight regarding the use of media elearning. The graph related to the effectiveness of using e-learning media instead of media youtube can be seen in the image below.

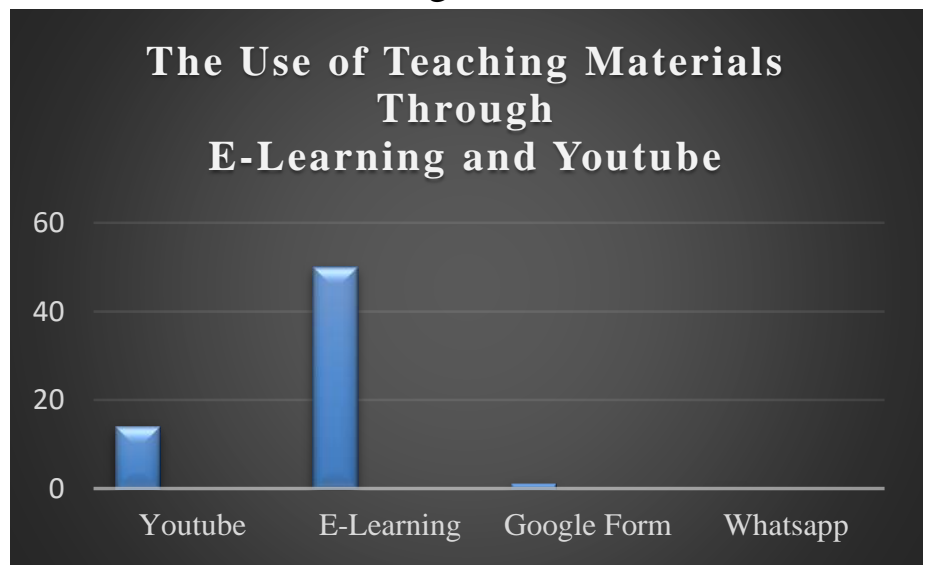

Figure 2. The Use of Teaching Materials Through E-Learning and Youtube

Media is one of the tools that can be used by a teacher in conveying information optimally. So that the media can improve the quality of learning and increase the knowledge gained by students (Isran Rasyid Karo-Karo S, 2018). The use of media e-learning in teaching physical education and health sports also can reduce the boredom experienced by students during the learning process is done online. Students are also very happy if in the learning process the teacher uses media more often e-learning than youtube. This is because media e-learning is very effective in supporting the learning process. Students can also follow the learning process simply by having the device android. This media is also very easy to access anywhere so students do not need to adjust the place in accessing this media. The 
Jendral A. Yani Street Lorong Gotong Royong 9/10 Ulu Palembang South Sumatera

\section{Accredited}

email jurnal: jurnalhon@univpgri-palembang.ac.id situs web: http://www.univpgri-palembang.ac.id

school also provides tools with sufficient capacity to maximize the use of this media e-learning.

This media e-learning is one of the learning innovations that can make a major contribution to changes in teaching and learning activities (Muhammad Rayhan Affandi., Maryscha Widyawati., 2020). When compared to media, youtube students understand the material better by using media elearning. Although in the $e$-learning video, the duration is limited. The graph related to the use of media e-learning can minimize the boredom experienced by students and students are happier if a teacher uses media more often elearning than youtube in learning physical education, sports and health can be seen in the image below.

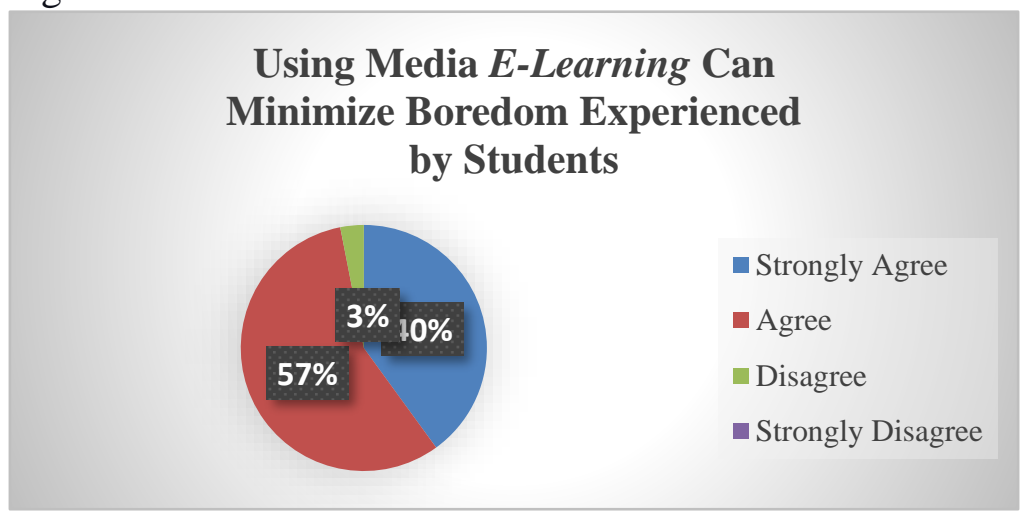

Figure 3. Use of Media E-Learning Can Minimize Boredom Experienced by Students

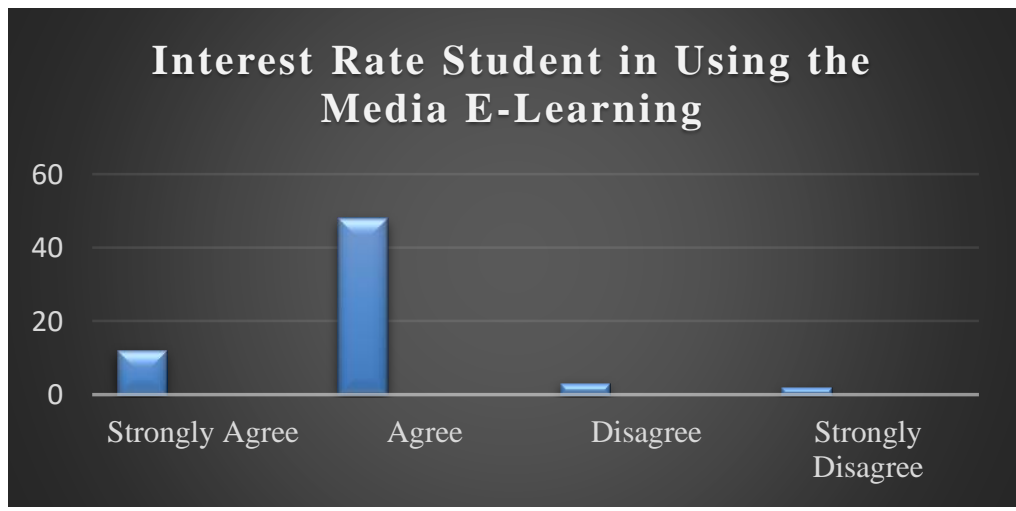

Figure 4. Interest Rate Students in Using the Media E- Learning 
Learning that is done online is certainly not as much as learning that is done offline. Even though a teacher does not stop making updates regarding the use of the media used. In this global era, of course, it is related to information technology. So that the use of media e-learning can help students to learn independently and be able to improve student's skills in the learning process (Sudaryanto, 2017). The use of social media certainly has positive and negative values. However, judging by the data obtained by the researcher, students in utilizing balanced technology. That is between the use of social media used for games, with learning physical education, sports, and health, which takes about 1-2 hours. So that the use of media e-learning tends to have a positive value.

The cards used by students are certainly very diverse. However, based on the results of the data obtained by the researcher, the majority of students filled in the data using a Telkomsel card. The card is quite stable in terms of internet connection than the other cards. So that it can maximize the learning process carried out online. Students who want to take part in the learning process certainly need pulses to be used in the learning process. So that students must top up the credit on each of their androids. The graph related to the balance of the use of social media used by students during the learning process of sports and health physical education by playing games can be seen in the image below.

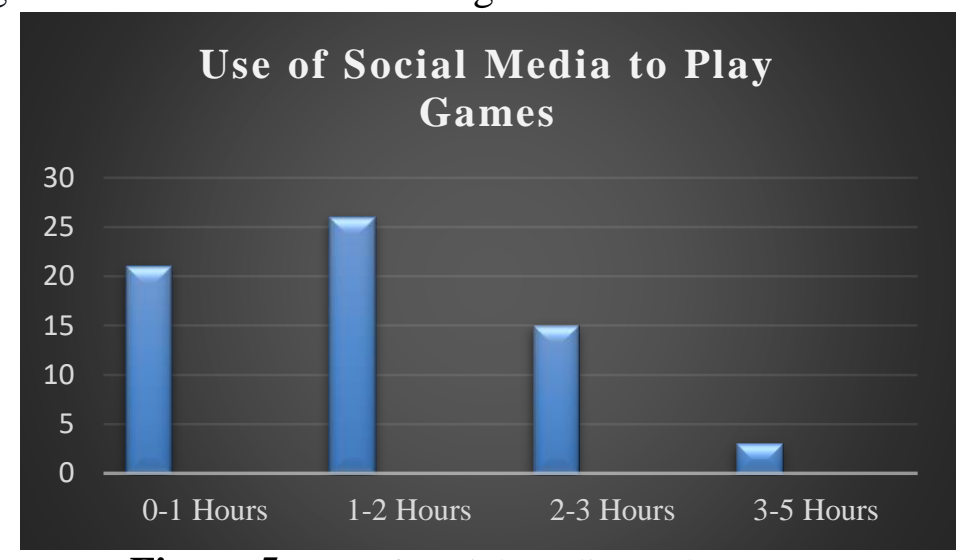

Figure 5. Use of Social Media to Play Games 
HALAMAN Jendral A. Yani Street Lorong Gotong Royong 9/10 Ulu

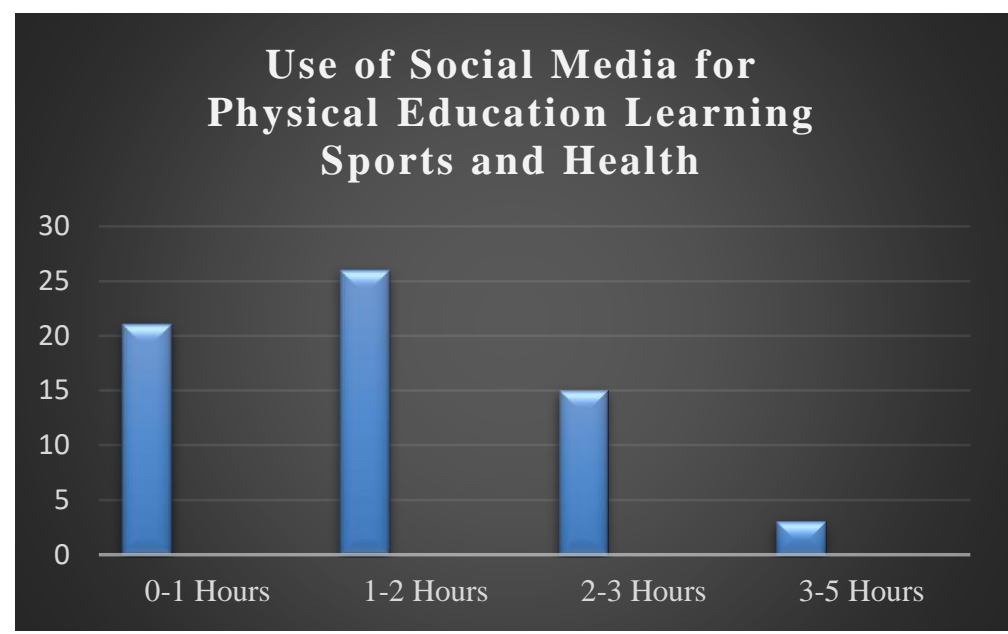

Figure 6. Use of Social Media for Learning Physical Education Sports and Health

Sports education is part of a regular and continuous educational process to acquire knowledge, personality, skills, health, and physical fitness (Wijayanto, 2018). So that the purpose of education is that students are expected to have adequate basic movement skills. In the teaching and learning process, of course, teaching materials have a very important role and influence the learning objectives. This is of course a material consideration in making teaching materials so that they can adapt to what is needed by students and teachers can apply it.

The effectiveness of using teaching materials through media $e$-learning, besides being able to help students understand the material, can also improve student learning outcomes, especially in physical education, sports, and healthy subjects. One of the influencing factors is the existence of an interest in participating in the learning process. The use of media used by teachers is very influential on the results to be achieved by students. Therefore, a teacher must be able to choose media that is suitable for use in the teaching and learning process. One example is that teachers can use this media e-learning as a tool in achieving the learning objectives to be achieved. Because this media is quite interesting for students to participate in the learning process. So that this media e-learning is quite effective in using the learning process online. Although this media e-learning has an advantage 
in the learning process, it also has a weakness when applied. One example of the weakness of using this media e-learning is that it cannot upload too many videos and students can send assignments in the form of photos only once.

\section{CONCLUSION}

Based on the results of research conducted by researchers related to the effectiveness of the use of teaching materials through media $e$ learning and youtube in improving learning outcomes of physical education, sports, and health, it was found that media e-learning in web form was more effectively used than media youtube in the learning process carried out. online. This is influenced by the fact that media is e-learning very easy to apply and does not drain too much memory. This media e-learning can also be accessed anywhere and does not need a stable network. So that students can follow the learning process to the fullest. The device used in accessing this media e-learning is enough to use Android which of course all students already have. This media e-learning can also minimize the boredom experienced by students during the learning process. In everyday life, students will not be able to escape from using social media. Whether it is used in terms of playing games or used as a tool in participating in the learning process of physical education, sports, and health. However, in this case, it is known that students are balanced in using social media to play games and follow the learning process. So that the use of this media can maximize the learning process and can improve learning outcomes.

\section{ACKNOWLEDGMENTS}

The authors express gratitude to Allah SWT for all His graces and gifts in providing fluency, strength, and patience in compiling research to article publication. The author also does not forget to say many thanks to all parties and reviewers who helped/supported in reviewing the article manuscript. May Allah SWT rewards the goodness and it will be recorded as a charity. Amen Ya Rabbal Alamin. 


\section{REFERENCES}

Andi Prastowo. (2016). Pengembangan Bahan Ajar Tematik Tinjauan Teoritis dan Praktik (ke 2). Kencana.

Arisman, A. (2018). Pengaruh Latihan Skj 2012 Terhadap Kebugaran Jasmani Siswa Smp Negeri 35 Palembang. Wahana Didaktika: Jurnal Ilmu Kependidikan, 16(2),

173. https://doi.org/10.31851/wahanadidaktika.v16i2.2047

Asri, N., \& Lely Octaviana, E. S. (2021). Aktivitas Olahraga Di Masa Pandemi COVID-19 Terhadap Tingkat Stres Mahasiswa Pendidikan Olahraga Universitas Islam Kalimantan Muhammad Arsyad Al Banjari Banjarmasin. Halaman Olahraga Nusantara (Jurnal Ilmu Keolahragaan). https://doi.org/10.31851/hon.v4i1.5213

Babitha Elsa Oommen. (2020). Impact of Social Media on Sustainable Development. International Journal of Science and Research, 9(11), 16891691. https://doi.org/10.21275/SR201126192153

Chenicheri Sid Nair Arun Patil Patricie Mertova. (2012). Echancing learning and teaching through student feedback in engineering. 16th January.

Clarence Mybee. (2018). Impact Learning:Librarians at the forefront of change in higher education. 20th February.

Helge, Kris, D. (2013). The Teaching Librarian: Web 2.0, Technology, and Legal Aspect. 31st October.

Isran Rasyid Karo-Karo S, . Rohani. (2018). Manfaat media dalam pembelajaran. Axiom, $\operatorname{VII}(1)$.

Lies Sudibyo. (2011). Peranan dan Dampak Teknologi Informasi dalam Dunia Pendidikan di Indonesia. Widyatama, 2(2), 22.

Mark Latash., V. Z. (2015). Biomechanics and Motor Control.

Muhammad Rayhan Affandi., Maryscha Widyawati., Y. B. B. (2020). analisis efektivitas media pembelajaran e-learning dalam meningkatkan hasil belajar siswa kelas x pada pelajaran fisika. Jurnal Pendidikan Fisika, VIII(2), 150157. https://doi.org/http://dx.doi.org/10.24127/ipf.v8i2.2910 
Pebria Dheni Purnasari. (2020). Pemanfaatan Teknologi Dalam Pembelajaran Sebagai Upaya Peningkatan Kompetesnsi Pedagogik. Jurnal Publikasi Pendidikan, 10(3), 189-196.

Sabaruddin Yunis Bangun. (2016). Peran Pendidikan Jasmani dan Olahraga Pada Lembaga Pendidikan di Indonesia. Publikasi Pendidikan, 6(3).

Sabarudin. (2016). Peran Pendidikan Jasmani dan Olahraga pada Lembaga Pendidikan di Indonesia. Publikasi Pendidikan, 2(1), 156-167. https://doi.org/DOI: https://doi.org/10.26858/publikan.v6i3.2270

Silahuddin. (2015). Penerapan e-learning dalam inovasi pendidikan. jurnal ilmiah circuit, 1(1), 48-59.

Sudaryanto, D. H. (2017). Pemanfaatan E-Learning Sebagai Media Pembelajaran Mandiri. Forum Diklat.

Syarif Sumantri. (2017). Teori dan Praktek di Tingkat Pendidikan Dasar. In Raja Grafindo Persada.

Urs Gttiker. (2013). Social Media Audit. 31st October.

Wahyuningtyas, R., \& Sulasmono, B. S. (2020). Pentingnya Media dalam Pembelajaran Guna Meningkatkan Hasil Belajar di Sekolah Dasar. Edukatif: jurnal ilmu pendidikan. https://doi.org/10.31004/edukatif.v2i1.77

Wayang Cong Sujana. (2019). Fungsi dan Tujuan Pendidikan Indonesia. Pendidikan Dasar, 2(3).

Wijayanto, A. (2018). Pengaruh metode guided discovery, dan metode movement exploration serta persepsi kinestetik terhadap hasil belajar pukulan atas bulutangkis pada mahasiswa iain tulungagung. Halaman Olahraga Nusantara (Jurnal Ilmu Keolahragaan). https://doi.org/10.31851/hon.v1i2.1976

Zaheer Allam. (2020). Surveying the Covid-19 Pandemic and Its Implications. 